\title{
Hubungan Tingkat Pengetahuan dengan Kepatuhan Terapi ARV pada ODHA di Yogyakarta
}

\section{The Correlation between The Level of Knowledge and The Adherence on ARV Therapy of ODHA in Yogyakarta}

\author{
Erika Agustin Wulandari ${ }^{1}$, Dwi Kartika Rukmi2* \\ ${ }^{1}$ Program Studi IImu Keperawatan, Fakultas Kesehatan, Universitas Jenderal Achmad Yani, \\ Yogyakarta \\ 2Departemen Keperawatan Medikal Bedah, Program Studi Ilmu Keperawatan, Fakultas \\ Kesehatan, Universitas Jenderal Achmad Yani, Yogyakarta
}

\begin{abstract}
Background: Knowledge is something that can influence individual behaviour, and it is also one of the factors that can affect adherence. On the other hand, an individual who has knowledge about HIV/AIDS does not always has good adherence to ARV (antiretroviral) therapy.

Objective: Determine the correlation between the level of HIV/AIDS knowledge with the adherence to ARV therapy in people living with AIDS (PLWHA) at the Victory Plus Foundation, Yogyakarta.

Methods: This research was a correlative analytic study with a cross-sectional design approach. A total of 67 PLWHA who underwent ARV therapy at the Victory Plus Foundation Yogyakarta were chosen as respondents through purposive sampling technique, between May and July 2019. Data collection used the HIV/AIDS Knowledge Level Questionnaire and The Morisky Medication Adherence Scale (MMAS8), which have been considered as valid and reliable. Somers' D Test used to analyze obtained data.

Results: The level of knowledge of PLWHA in this study was in the high category $(92,5 \%)$, while adherence to ARV therapy was in the moderate category (40,3\%). There is no significant correlation between the level of knowledge and adherence to ARV therapy $(r=0,113 ; p$-value= 0,153$)$.

Conclusion: The level of knowledge of HIV patients undergoing ARV therapy at the Victory Plus Foundation Yogyakarta is high and their adherence to ARV therapy is moderate, but there is no relationship between these two variables. Consequently, healthcare provider should focus on other scientific-proven factors, than HIV/AIDS knowledge, to increase ARV therapy adherence among patients for successful HIV treatment.
\end{abstract}

Keywords: ARV, adherence, HIV, level of knowledge, PLWHA

\section{ABSTRAK}

Latar Belakang: Pengetahuan merupakan salah satu faktor yang dapat memengaruhi perilaku individu dan kepatuhan. Namun, individu yang memiliki pengetahuan yang baik tentang HIV/AIDS tidak selalu memiliki kepatuhan terapi ARV (antiretroviral) yang baik.

Tujuan: Mengetahui hubungan tingkat pengetahuan HIV/AIDS dengan kepatuhan terapi ARV pada orang dengan HIV AIDS (ODHA) di Yayasan Victory Plus Yogyakarta.

Metode: Penelitian ini merupakan penelitian analitik korelatif dengan pendekatan desain cross sectional. Sebanyak 67 ODHA yang menjalani terapi ARV di Yayasan Victory Plus Yogyakarta dipilih sebagai responden dengan teknik purposive sampling, antara bulan Mei hingga Juli 2019. Pengumpulan data menggunakan kuesioner Tingkat Pengetahuan HIV/AIDS dan Morisky Medication Adherence Scale (MMAS-8), yang sudah valid dan reliabel. Uji Somers' D digunakan untuk menganalisis data yang diperoleh.

Hasil: Tingkat pengetahuan ODHA dalam penelitian ini termasuk dalam kategori tinggi $(92,5 \%)$, sedangkan kepatuhan terapi ARV dalam kategori sedang (40,3\%). Tidak ada hubungan yang signifikan antara tingkat pengetahuan dengan kepatuhan terapi ARV $(r=0,113 ; p$-value $=0,153)$. 
Kesimpulan: Tingkat pengetahuan pasien HIV yang menjalani terapi ARV di Yayasan Victory Plus Yogyakarta tinggi dan kepatuhan terapi ARV sedang, tetapi tidak ada hubungan antara kedua variabel tersebut. Dampaknya, penyedia layanan kesehatan harus fokus pada faktor-faktor ilmiah lain, selain pengetahuan HIV/AIDS, agar dapat meningkatkan kepatuhan terapi ARV di antara pasien untuk pengobatan HIV yang berhasil.

Kata kunci: ARV, HIV, kepatuhan, ODHA, tingkat pengetahuan

\section{PENDAHULUAN}

Penyakit Human Immunodeficiency Virus (HIV) sudah menjadi masalah kesehatan yang membutuhkan perhatian serius di seluruh dunia. Berdasarkan data dari WHO, jumlah angka penderita HIV semakin meningkat setiap tahunnya. Pada tahun 2013 penderita HIV tercatat sejumlah 32,1 juta jiwa, dan bertambah menjadi 36,9 juta jiwa pada tahun 2017. ${ }^{1}$ Begitupun di Indonesia, kasus HIV juga mengalami peningkatan yang signifikan dari jumlah 21.511 pada tahun 2012, menjadi 41.250 pada tahun 2016 . $^{2}$ Sama dengan gambaran kasus HIV nasional, prevalensi HIV di Yogyakarta juga mengalami peningkatan, dari jumlah 1.323 pada tahun 2013 menjadi 3.937 pada tahun 2017. ${ }^{3}$ Hal ini menjadikan Yogyakarta berada di urutan ke 13 dengan jumlah infeksi HIV terbanyak di Indonesia. ${ }^{4}$

HIV merupakan penyakit yang menyerang sistem kekebalan tubuh manusia sehingga kemampuan tubuh untuk melawan berbagai penyakit mengalami gangguan. Sementara Acquired Immune Deficiency Syndrome (AIDS) merupakan kumpulan gejala penyakit yang disebabkan oleh HIV. ${ }^{5}$ Cara penularan HIV terbanyak di Indonesia adalah melalui hubungan heteroseksual $(70 \%)$, dan homoseksual (22\%). Sementara untuk penularan melalui jarum suntik, perinatal, biseks, transfusi darah, dan lain-lain, angka penularannya berkisar antara 0$2 \%{ }^{4}$

Mengontrol penyebaran HIV telah dilakukan melalui berbagai cara, antara lain abstinence (menahan keinginan untuk melakukan hubungan seksual), penggunaan kontrasepsi (kondom), dan penggunaan jarum suntik steril yang memiliki tingkat keberhasilan beragam di berbagai negara. ${ }^{6}$ Selain itu, pemerintah Indonesia juga sudah mengupayakan penanggulangan HIV/AIDS melalui Permenkes RI No. 21 tahun 2013, dengan bentuk kegiatan promosi dan pencegahan penularan HIV, pemeriksaan diagnosis HIV, pengobatan, perawatan, pemberian dukungan serta rehabilitasi. ${ }^{7}$

Kepatuhan penggunaan obat ARV memberikan dampak positif bagi kesehatan individu. Hal ini disebabkan semakin banyak Orang dengan HIV AIDS (ODHA) yang diobati, maka manfaatnya dalam menuju "3 zero", yaitu zero infeksi baru, zero kematian terkait AIDS, zero stigma dan diskriminasi semakin besar. ${ }^{8}$ Untuk menuju tujuan tersebut, hal penting yang harus diperhatikan adalah pengetahuan ODHA terkait dengan penyakit dan manajemen terapinya. 
Pengetahuan merupakan komponen utama dalam pembentukan perilaku seseorang. Apabila didasari oleh pengetahuan, maka perilaku akan lebih baik terbentuk daripada perilaku yang tidak didasari oleh pengetahuan. ${ }^{9}$ Pengetahuan ODHA yang baik menjadi landasan untuk memotivasi dirinya berperilaku patuh terhadap pengobatan yang sedang dijalani. ${ }^{10}$

Berdasarkan hasil studi pendahuluan yang dilakukan pada 14 Desember 2018 di Yayasan Victory Plus melalui wawancara terhadap 6 ODHA, didapatkan hasil bahwa semua (100\%) responden dapat menggambarkan secara jelas bagaimana seseorang dapat terinfeksi HIV dan hal apa yang harus dilakukan setelah terinfeksi, dan proses terapi untuk HIV. Namun, untuk gambaran kepatuhan antiretroviral (ARV) didapatkan 4 orang (66\%) tidak patuh minum ARV dengan alasan malas minum ARV karena bosan dan sibuk dengan aktivitasnya. Kurangnya pengetahuan atau informasi, berhubungan secara signifikan dengan kepatuhan terapi ARV. ${ }^{11}$ Sementara kepatuhan merupakan hal yang sangat penting untuk kesuksesan terapi HIV dan ARV sebagai satu-satunya terapi untuk HIV saat ini, merupakan fakta yang tidak terbantahkan. ${ }^{11}$

Dari hasil studi pendahuluan, ditunjukkan adanya kemungkinan ketidaksesuaian antara pengetahuan dan perilaku pada ODHA terkait dengan terapi HIV di Yayasan Victory Plus Yogyakarta. Selain itu, penelitian terkait hubungan antara pengetahuan dan kepatuhan pasien HIV, belum pernah dilakukan sebelumnya di Yayasan Victory Plus. Oleh karena itu, penelitian hubungan tingkat pengetahuan dengan kepatuhan terapi ARV pada ODHA ini penting untuk dilakukan. Tujuan dari penelitian ini adalah untuk mengetahui hubungan tingkat pengetahuan dengan kepatuhan terapi ARV pada ODHA di Yayasan Victory Plus Yogyakarta.

\section{METODE PENELITIAN}

Penelitian ini adalah penelitian analitis korelatif dengan rancangan cross-sectional. Penelitian ini dilakukan di Yayasan Victory Plus Yogyakarta pada 25 Mei-7 Juli 2019, terhadap 67 ODHA sebagai responden, yang diambil dengan teknik purposive sampling. Kriteria inklusi sampel adalah ODHA yang bisa membaca dan menulis, telah melewati pendidikan dasar, berusia $>18$ tahun, dan sedang menggunakan ARV.

Pengumpulan data untuk tingkat pengetahuan terkait HIV/AIDS menggunakan kuesioner pengetahuan HIV/AIDS yang berisi 38 unit pertanyaan dan disusun oleh peneliti. Sementara untuk mengukur tingkat kepatuhan terhadap terapi ARV, data diambil menggunakan kuesioner The 8-Item Morisky Medication Adherence Scale (MMAS-8) yang berisi 8 unit pertanyaan. ${ }^{12}$

Uji validitas dan reliabilitas MMAS-8 versi Bahasa Indonesia telah dilakukan pada tahun 2015 oleh Rosyida et al. ${ }^{13}$ dengan hasil $r_{\text {hitung }}>r_{\text {tabel }}(0,355)$ dan hasil koefisien reliabilitas Alpha Cronbach sebesar 0,729, yang menunjukkan bahwa kuesioner MMAS-8 yang digunakan telah valid dan reliabel. Sementara untuk kuesioner pengetahuan tentang HIV/AIDS telah dilakukan Uji Content Validity Index (CVI) dengan hasil 1 (valid) dan uji reliabilitas dengan hasil 0,34. 
Kategorisasi untuk pengetahuan menggunakan persentase yaitu termasuk kategori pengetahuan tinggi (jawaban benar 76-100\%), pengetahuan sedang (jawaban benar 56-75\%), dan pengetahuan rendah (jawaban benar <55\%). ${ }^{14}$ Dalam penelitian ini, pengetahuan termasuk tinggi apabila skor 33-38, pengetahuan sedang pada skor 28-32, dan pengetahuan rendah apabila skor <28. Kategorisasi untuk kepatuhan dibagi menjadi tiga yaitu kategori kepatuhan tinggi untuk skor 8, kepatuhan sedang untuk skor 6-7, dan tingkat kepatuhan rendah untuk skor $<6 .{ }^{12}$

Analisis data untuk melihat kekuatan hubungan antara pengetahuan HIV/AIDS dengan kepatuhan ARV dalam penelitian ini menggunakan Uji Somers' $D$, mengingat kedua variabel berskala ordinal.

\section{HASIL}

Karakteristik responden dalam penelitian ini tercantum pada Tabel 1. Berdasarkan hasil pada Tabel 1, terlihat bahwa rata-rata usia responden adalah 33,8 $\pm 9,4$ tahun. Mayoritas responden berjenis kelamin laki-laki $(73,1 \%)$, berstatus belum menikah $(64,2 \%)$, memiliki pekerjaan (64,2\%), berlatar belakang pendidikan SMA $(62,7 \%)$, dan lama terapi $A R V$ responden memiliki nilai tengah sekitar 30 bulan.

Tabel 1. Karakteristik responden yang menjalani terapi ARV di Yayasan Victory Plus $(n=67)$

\begin{tabular}{|c|c|c|c|}
\hline Karakteristik & f (\%) & Mean \pm SD & Median (Min-Max) \\
\hline Usia (tahun) & & $33,8 \pm 9,4$ & \\
\hline \multicolumn{4}{|l|}{ Jenis kelamin } \\
\hline Laki-laki & $49(73,1)$ & & \\
\hline Perempuan & $18(26,9)$ & & \\
\hline \multicolumn{4}{|l|}{ Status pernikahan } \\
\hline Belum Menikah & $44(65,7)$ & & \\
\hline Menikah & $15(22,4)$ & & \\
\hline Duda/Janda & $8(11,9)$ & & \\
\hline \multicolumn{4}{|l|}{ Status pekerjaan } \\
\hline Bekerja & $43(64,2)$ & & \\
\hline Tidak Bekerja & $24(35,8)$ & & \\
\hline \multicolumn{4}{|l|}{ Tingkat pendidikan } \\
\hline SMP & $12(17,9)$ & & \\
\hline SMA & $42(62,7)$ & & \\
\hline Perguruan Tinggi & $13(19,4)$ & & \\
\hline Lama terapi ARV (dalam bulan) & & & $30,0(1-168)$ \\
\hline Baru (< 6 bulan) & $20(29,9)$ & & \\
\hline Lama ( $\geq 6$ bulan) & $47(70,1)$ & & \\
\hline
\end{tabular}

Tingkat pengetahuan ODHA mengenai HIV/AIDS, yang menjalani terapi ARV di Yayasan Victory Plus Yogyakarta tercantum pada Tabel 2. Pada Tabel 2 menunjukkan bahwa mayoritas tingkat pengetahuan HIV/AIDS pada ODHA di Yayasan Victory Plus Yogyakarta berada dalam kategori tinggi yaitu $62(92,5 \%)$. 
Tabel 2. Gambaran tingkat pengetahuan ODHA tentang HIV/AIDS di Yayasan Victory Plus Yogyakarta $(n=67)$

\begin{tabular}{lcc}
\hline \multicolumn{1}{c}{ Tingkat Pengetahuan } & Frekuensi (f) & Persentase (\%) \\
\hline Rendah (<28) & 0 & 0,0 \\
Sedang (28-32) & 5 & 7,5 \\
Tinggi (33-38) & 62 & 92,5 \\
\hline
\end{tabular}

Gambaran tingkat kepatuhan ODHA di Yayasan Victory Plus Yogyakarta pada penelitian ini disajikan pada Tabel 3. Pada Tabel 3 menunjukkan bahwa mayoritas gambaran kepatuhan terapi ARV pada ODHA di Yayasan Victory Plus Yogyakarta dalam kategori sedang (40,3\%).

Tabel 3. Gambaran kepatuhan terapi ARV pada ODHA di Yayasan Victory Plus Yogyakarta $(n=67)$

\begin{tabular}{lcc}
\hline \multicolumn{1}{c}{ Tingkat Kepatuhan } & Frekuensi (f) & Persentase (\%) \\
\hline Rendah (<6) & 26 & 38,8 \\
Sedang (6-7) & 27 & 40,3 \\
Tinggi (8) & 14 & 20,9 \\
\hline
\end{tabular}

Hubungan tingkat pengetahuan dengan kepatuhan terapi ARV pada ODHA tercantum dalam Tabel 4. Hasil uji Somers' $D$ pada Tabel 4 didapatkan hasil $p=0,153(\geq 0,05)$ yang berarti tidak terdapat hubungan antara tingkat pengetahuan HIV/AIDS dengan kepatuhan terapi ARV. Hasil uji juga menunjukkan bahwa kekuatan hubungan antara kedua hal tersebut adalah 0,113, yang berarti memiliki keeratan hubungan yang sangat lemah.

\begin{tabular}{|c|c|c|c|c|c|}
\hline \multirow[b]{2}{*}{$\begin{array}{c}\text { Tingkat } \\
\text { Pengetahuan }\end{array}$} & \multicolumn{3}{|c|}{ Kepatuhan } & \multirow[b]{2}{*}{$p$ value } & \multirow[b]{2}{*}{$r$ Somer's $D$} \\
\hline & $\begin{array}{c}\text { Rendah } \\
f(\%)\end{array}$ & $\begin{array}{c}\text { Sedang } \\
f(\%)\end{array}$ & $\begin{array}{c}\text { Tinggi } \\
f(\%)\end{array}$ & & \\
\hline Sedang & $3(60,3)$ & $2(40,0)$ & $0(0,0)$ & 0,153 & 0,113 \\
\hline Tinggi & $23(37,1)$ & $25(40,3)$ & $14(22,6)$ & & \\
\hline
\end{tabular}

\section{PEMBAHASAN}

Hasil penelitian menunjukkan rata-rata usia responden adalah $33,8 \pm 9,4$ hal ini sejalan dengan penelitian Widayati \& Murtaqib $^{15}$ yang mendapati rerata usia penderita HIV/AIDS dalam penelitiannya adalah $36 \pm 9,5$ tahun. Kedua rerata usia dalam penelitian tersebut menunjukkan bahwa mayoritas penderita HIV/AIDS di Indonesia berada pada kelompok usia produktif yaitu berusia 15-64 tahun. ${ }^{16} \mathrm{Hal}$ ini mendukung dengan data dari Kemenkes RI yang menunjukkan bahwa sebanyak 62,9\% ODHA di Indonesia berada pada kategori usia 25- 49 tahun. $^{2}$ Gobel \& Risco ${ }^{17}$ menjelaskan bahwa rasa ingin tahu pada usia produktif ini akan menyebabkan seseorang terjerumus dalam perilaku seks bebas sehingga penularan HIV/AIDS pun meningkat pada usia produktif.

Mayoritas responden berjenis kelamin laki-laki 49 orang $(73,1 \%)$. Hal ini sesuai dengan penelitian Nyoko, et al. bahwa dari 111 orang dalam penelitiannya, sebanyak 73 orang $(64,9 \%)$ 
penderita HIV/AIDS adalah laki-laki. ${ }^{18}$ Laporan dari Kemenkes $\mathrm{RI}$ juga menyatakan bahwa proporsi laki-laki lebih banyak dibandingkan perempuan. ${ }^{2}$ Rasio responden laki-laki dan perempuan yang terkena HIV/AIDS dalam penelitian ini adalah $2: 1$ (73,1\% vs 26,9\%). Irmaningrum et al. dalam Kambu et al. ${ }^{19}$ menyebutkan bahwa tingginya penderita HIV/AIDS pada laki-laki dikarenakan yang lebih rentan melakukan perilaku seksual berisiko adalah kelompok laki laki dibandingkan perempuan. Hasil penelitian Yusri et al. ${ }^{20}$ di RSUP H. Adam Malik Medan mendapati penularan paling banyak dari HIV adalah melalui hubungan seksual (73\%), kemudian penularan melalui darah dan produk darah (27\%).

Mayoritas responden dalam penelitian ini belum menikah $(65,7 \%)$. Penelitian ini sesuai dengan hasil penelitian Ibrahim et al. di Bandung bahwa mayoritas status pernikahan ODHA adalah belum menikah (50,6\%). ${ }^{21}$ Namun, hasil penelitian ini tidak sesuai dengan penelitian Nyoko, et al. ${ }^{18}$ tentang Karakteristik Pasien HIV di Sumba Timur Tahun 2010-2016, diperoleh hasil bahwa dari 111 orang, sebanyak 69 orang (62,2\%) ODHA sudah menikah. Seseorang tidak bisa terlindungi dari terinfeksi HIV hanya dengan pernikahan dan kesetiaan. ${ }^{22}$ Berdasarkan data The Joint United Nations Programme on HIV/AIDS (UNAIDS) ${ }^{23}$ di Afrika dilaporkan sebanyak $66 \%$ penduduknya setia pada pasangan dan $79 \%$ tidak melakukan hubungan seksual, tetapi didapatkan hasil $40 \%$ perempuan terinfeksi HIV padahal hanya memiliki 1 pasangan. Di Kolombia dilaporkan bahwa 72\% wanita yang baru menikah terinfeksi dari suami mereka. ${ }^{23}$

Mayoritas responden dalam penelitian ini memiliki pekerjaan atau berstatus bekerja $(64,2 \%)$. Penelitian ini mendukung penelitian Budiono et al. ${ }^{24}$ yang juga menemukan bahwa $62 \%$ dari ODHA yang menjadi responden dalam penelitiannya berstatus bekerja. Kemenkes $\mathrm{RI}$ menyebutkan bahwa pekerjaan juga dapat memengaruhi risiko seseorang terkena HIV, sebagai contoh adalah pekerja seks komersial yang memiliki risiko besar terkena penyakit $\mathrm{HIV}^{2}$ Notoatmodjo juga menyatakan bahwa beberapa jenis pekerjaan memiliki peran untuk

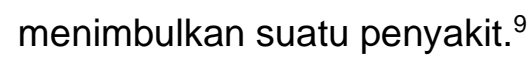

ODHA di Yayasan Victory Plus Yogyakarta mayoritas berlatar belakang pendidikan SMA $(62,7 \%)$. Penelitian ini mendukung dengan penelitian Yuliandra ${ }^{25}$ yang mendapati tingkat pendidikan ODHA terbanyak pada respondennya adalah tingkat pendidikan menengah. Pendidikan dapat memengaruhi seseorang dalam melakukan tindakan dan memilih sikap yang tepat. ${ }^{26}$ Pendidikan merupakan salah satu faktor yang dapat memengaruhi persepsi seseorang akan sesuatu, dapat mendukung perilaku pencarian pengobatan, meningkatkan kualitas hidup, selain itu meningkatkan kebutuhan tentang informasi dasar HIV dan meningkatkan upaya pengobatan. ${ }^{27}$

Mayoritas responden menjalani terapi ARV sekitar 1-168 bulan dengan nilai tengah (median) 30 bulan. Terapi ARV harus dilakukan oleh ODHA seumur hidup. ${ }^{8}$ Lama terapi ARV dalam penelitian ini dikategorikan menjadi kategori baru dan kategori lama. Kategori baru 
adalah ODHA yang menjalan terapi $A R V<6$ bulan, sedangkan kategori lama yaitu ODHA yang menjalani terapi ARV $>6$ bulan. Pada penelitian ini terdapat 20 ODHA termasuk dalam kategori baru. Penelitian Kambu et al. ${ }^{19}$ yang dilakukan pada 75 responden menemukan bahwa mayoritas lama terapi $>6$ bulan sebesar 54 orang $(72 \%)$ dan pada ODHA yang sudah terinfeksi lama, masih dapat menularkan HIV, sehingga penularan ini terjadi seperti fenomena gunung es.

Hasil penelitian ini juga mendapati bahwa mayoritas tingkat pengetahuan HIV/AIDS pada ODHA di Yayasan Victory Plus Yogyakarta masuk dalam kategori tinggi (92,5\%). Hasil ini sejalan dan memiliki persentase yang lebih tinggi daripada hasil pada penelitian Septiansyah, et al. $^{28}$ yang menyebutkan bahwa dari 41 responden, sebanyak 26 responden $(64,41 \%)$ memiliki tingkat pengetahuan yang tinggi. Hasil penelitian lain yang dilakukan oleh Debby, et al. ${ }^{29}$ di Unit Pelayanan Terpadu RSUPN Dr. Cipto Mangunkusumo juga sejalan dengan hasil penelitian ini, dengan mayoritas pengetahuan ODHA berada dalam kategori baik (70,2\%).

Pengetahuan yang baik dapat terbentuk dari edukasi. Hal ini sejalan dengan penelitian Anggraini tentang edukasi kepada pasien HIV dapat berpengaruh terhadap pengetahuan dengan $p=0,03<(0,05) .{ }^{30}$ Walaupun penelitian ini tidak berfokus pada edukasi, namun alasan mengapa pengetahuan ODHA terkait HIV/AIDS dalam penelitian ini tinggi, bisa disebabkan karena adanya upaya edukasi kontinu yang dilakukan oleh Yayasan Victory Plus. Yayasan Victory Plus Yogyakarta ini rutin mengadakan seminar setiap 2 minggu sekali, dari kelompok dukungan sebaya. Seminar juga dilakukan oleh pengurus yayasan maupun dari pihak luar yang membantu ODHA baru, untuk mengetahui berbagai hal terkait penyakitnya dan agar patuh dalam mengonsumsi obat.

Berdasarkan hasil penelitian didapatkan kepatuhan terapi ARV pada ODHA di Yayasan Victory Plus Yogyakarta berada pada kategori kepatuhan sedang, meskipun hanya selisih 1 responden pada kategori kepatuhan rendah. Penelitian ini sejalan dengan penelitian Galistiani \& Mulyaningsih ${ }^{31}$ di RSUD Prof. Dr. Margono Soekarjo Purwokerto dan penelitian Septiansyah, et al. ${ }^{28}$ di RSUPN Dr. Ciptomangunkusumo yang juga mendapati mayoritas responden dalam penelitiannya memiliki kepatuhan yang sedang terhadap terapi ARV. Tingkat kepatuhan sedang dipengaruhi oleh perilaku responden, seperti keyakinan sikap yang mampu memengaruhi motivasi, dan menjaga untuk tetap patuh minum obat. ${ }^{32}$ Kepatuhan sedang pada responden di Yayasan Victory Plus Yogyakarta paling sering ditunjukkan dengan perilaku mengulur waktu untuk minum obat karena sibuk bekerja dan bosan minum obat.

Hasil penelitian ini didapatkan bahwa tidak ada hubungan antara tingkat pengetahuan HIV/AIDS dengan kepatuhan terapi ARV pada ODHA di Yayasan Victory Plus Yogyakarta dengan ( $p=0,153 ; r=0,113$ ). Penelitian ini sejalan dengan penelitian Husna ${ }^{33}$ di RSUD dr. Zaenal Abidin Banda Aceh dan penelitian Sequera dan Alvares di India, ${ }^{34}$ bahwa tidak ada hubungan antara pengetahuan tentang HIV dengan kepatuhan dalam terapi ARV. Penderita 
HIV/AIDS yang memiliki pengetahuan baik, belum tentu memiliki kepatuhan yang tinggi. Pernyataan ini sesuai dengan hasil penelitian Khairunnisa et al. yang menemukan bahwa responden yang memiliki pengetahuan baik, sebagian besar malah tidak patuh dalam pengobatan ARV. ${ }^{35}$

Kepatuhan terapi ARV tidak hanya dapat dipengaruhi oleh tingkat pengetahuan saja, tetapi dipengaruhi oleh hal lain seperti faktor kesadaran individu dan motivasi diri, kesibukan (terutama bagi orang yang sudah bekerja), tidak tahan terhadap efek samping obat serta malas untuk mengambil obat ketika sudah habis. ${ }^{36}$ Menurut Debby et al. ${ }^{29}$ kepatuhan terapi ARV juga dipengaruhi oleh dukungan keluarga, pada ODHA yang memiliki dukungan positif dari keluarga akan mampu meningkatkan kepatuhan sebesar 53,7\% ( $p=0,034)$. Kepatuhan terapi ARV juga dapat dipengaruhi oleh motivasi internal dari ODHA untuk dapat sembuh dan bertahan hidup. Dengan adanya motivasi yang baik pada ODHA, akan berpengaruh terhadap optimisme hidup, semangat untuk bekerja, pikiran yang positif, dan patuh dalam menjalankan pengobatan ARV. ${ }^{37}$

Latif et al. ${ }^{8}$ dalam penelitiannya mendapatkan hasil, efek samping ARV menjadi faktor yang menyebabkan ODHA menjadi tidak patuh saat minum obat. Penelitian Anwar, et al. di RSPI Prof. Dr. Sulianti Saroso Jakarta, mendapati beberapa efek samping dari ARV yang dirasakan oleh responden adalah pusing (34,7\%), alergi (21,05\%), vomiting $(17,90 \%)$, insomnia $(7,36 \%)$, demam $(5,27 \%)$, anemia $(5,27 \%)$, diare $(3,15 \%)$, dan pucat $(5,27 \%)$. Hal tersebut dirasa mengganggu kenyamanan ODHA saat beraktivitas. ${ }^{38}$

\section{KESIMPULAN DAN SARAN}

Mayoritas ODHA di Yayasan Victory Plus Yogyakarta memiliki tingkat pengetahuan dalam kategori tinggi dan tingkat kepatuhan dalam kategori sedang. Tidak terdapat hubungan bermakna antara tingkat pengetahuan dengan kepatuhan terapi ARV pada ODHA di Yayasan Victory Plus Yogyakarta.

Perlu adanya upaya peningkatan kepatuhan pada pasien HIV dengan memperhatikan faktor selain pengetahuan tentang HIV/AIDS, seperti motivasi, efek samping ARV yang dialami ODHA, atau dukungan yang dibutuhkan oleh ODHA.

\section{UCAPAN TERIMA KASIH}

Penulis mengucapkan terima kasih kepada responden yang telah berpartisipasi pada penelitian ini, dan kepada Yayasan Victory Plus, serta kepada Universitas Jenderal Achmad Yani Yogyakarta, sehingga penelitian ini dapat berjalan dengan baik dan lancar.

\section{DAFTAR PUSTAKA}

1. World Health Organization. Global Action Plan on HIV Drug Resistance 2017-2021: 2018 Progress Report. 2018. Available from https://apps.who.int/iris/bitstream/handle/10665/273049/WHO-CDSHIV-18.12-eng.pdf? sequence=1\&isAllowed=y. 
2. Kementerian Kesehatan RI. Laporan Situasi Perkembangan HIV-AIDS \& Pims di Indonesia Tahun 2017. 2018. Available from: https://siha.kemkes.go.id/portal/perkembangan-kasus-hiv-aids pims\#.

3. Dinas Kesehatan Provinsi DIY. Profil Kesehatan Dinas Kesehatan Provinsi di Yogyakarta Tahun 2017. Yogyakarta: Dinas Kesehatan DIY; 2017.

4. Pusdatin RI. Infodatin HIV/AIDS [Internet]. 2020. Available from: https://pusdatin.kemkes.go.id/ resources/download/pusdatin/infodatin/infodatin-2020-HIV.pdf.

5. Aminoff M, Boller F, Swaab D. Handbook of Clinical Neurology: The Neurology of HIV Infection. 3rd Ed. Aminof MJ, Boller F, Swaab DF, Editors. Vol. 152, ELSEVIER. Amsterdam: Elsevier Inc.; 2018.

6. Rukmi DK, Darussalam M. Analisis Faktor yang Berhubungan dengan Keterbukaan Status HIV Seropositif Wanita Penderita HIV/AIDS terhadap Pasangan Seksual di LSM Victory Yogyakarta. Media IImu Kesehatan. 2018;7(2):114-22.

7. Menteri Kesehatan Republik Indonesia. Peraturan Menteri Kesehatan Republik Indonesia Nomor 21 Tahun 2013 tentang Penanggulangan HIV dan AIDS. 2013. Available from: https://www.kebijakanaidsindonesia.net/id/dokumen-kebijakan?task=download.send\&id=361\&cati $\mathrm{d}=17 \& \mathrm{~m}=0$.

8. Latif F, Maria IL, Syafar M. Efek Samping Obat terhadap Kepatuhan Pengobatan Antiretroviral Orang dengan HIV/AIDS. National Public Health Journal. 2014;9(2):101.

9. Notoadmodjo S. Promosi Kesehatan dan IImu Perilaku. Jakarta: Rineka Cipta; 2007.

10. Potchoo Y, Tchamdja K, Balogou A, Pitche VP, Guissou IP, Kassang EK. Knowledge and Adherence to Antiretroviral Therapy among Adult People Living with HIV/AIDS Treated in The Healthcare Centers of The Association "Espoir Vie Togo" in Togo, West Africa. BMC Clinical Pharmacology. 2010; 10.

11. Andrade Moraes D, Oliveira R, Prado A, Cabral J, Correa C, Albuquerque M. Knowledge of People Living with HIV/AIDS about Antiretroviral Therapy. Enfermeria Global. 2018;49:127-141.

12. Morisky DE, DiMatteo MR. Improving The Meassurement of Self-Reported Medication Nonadherence: Response to Authors. Journal of Clinical Epidemiology [Internet]. 2011;64(3):25563. Available from: https://www.ncbi.nlm.nih.gov/pmc/articles/PMC3624763/pdf/nihms412728.pdf.

13. Rosyida L, Priyandani Y, Nita Y. Kepatuhan Pasien pada Penggunaan Obat Anti-diabetes dengan Metode Pill-Count dan MMAS-8 di Puskesmas Kedurus. Jurnal Farmasi Komunitas. 2015;2(2):3641.

14. Arikunto. Prosedur Penelitian: Suatu Pendekatan Praktik. Jakarta: Rineka Cipta; 2010.

15. Widayati N, Murtaqib. Identifikasi Status Psikologi Sebagai Upaya Pengembangan Model Rehabilitasi Klien HIV/AIDS Berbasis Komunitas. NurseLine. 2016;1(1):90-9.

16. EOCD. Working Age Population (indicator) [Internet]. 2021. Available from: https://data.oecd.org/pop/working-age-population.htm.

17. Gobel B, Risco. Mikrobiologi Umum dalam Praktik. Makassar: Universitas Hasanuddin; 2008.

18. Nyoko Y, Hara M, Abselian U. Karakteristik Penderita HIV/AIDS di Sumba Timur Tahun 2010-2016. Jurnal Kesehatan Prima. 2016;1(1):4-15.

19. Kambu Y, Waluyo A, Kuntarti. Umur Orang dengan HIV AIDS (ODHA) Berhubungan dengan Tindakan Pencegahan Penularan HIV. Jurnal Keperawatan Indonesia. 2016;19(3):200-2017.

20. Yusri RA, Sarumpaet S, Rasmaliah. Karakteristik Penderita AIDS dan Infeksi Oportunistis di Rumah Sakit Umum Pusat (RSUP) H. Adam Malik Medan Tahun 2012. Jurnal USU. 2012;5(2):1-8.

21. Ibrahim K, Herliani Y, Rahayuwati L, Nurmalisa B, Fitri S. Hubungan antara Fatigue, Jumlah CD4, dan Kadar Hemoglobin pada Pasien yang Terinfeksi Human Immunodeficiency Virus (HIV). Jurnal Keperawatan Padjajaran. 2018;5(3):271-8.

22. Meehan J. Suicide in Mental Health in-Patients and Within 3 Months of Discharge. The British Journal of Psychiatry. 2006;188(2):129-34.

23. UN Joint Programme on HIV/AIDS (UNAIDS). AIDS Epidemic Update 2009 [Internet]. 2009. Available from: https://www.unaids.org/en/resources/publications/2009/20091124 jc1700 epi update 2009 en.pdf.

24. Budiono, Rantetampang A, Sandjaja B. The Factors Affecting of Adherence Drug Medicine ARV to Patient with HIV/AIDS at Paniai Regency. International Journal of Sciences: Basic Applied Research. 2017;32(1):280-98.

25. Yuliandra Y, Nosa U, Raveinal, Almasdy D. Terapi Antiretroviral pada Pasien HIV/AIDS di RSUP. Dr. M. Djamil Padang: Kajian Sosio-demografi dan Evaluasi Obat. Jurnal Sains Farmasi Klinik. 2017;4(1):1-8.

26. Notoadmodjo S. Pendidikan dan Perilaku Kesehatan. Jakarta: Rineka Cipta; 2003.

27. Burhan R. Pemanfaatan Pelayanan Kesehatan oleh Perempuan Terinfeksi HIV/AIDS. Jurnal Kesehatan Masyarakat Nasional. 2013;8(1):33-8. 
28. Septiansyah E, Fitriangga A, Irsan A. Faktor-faktor yang Berhubungan dengan Kepatuhan Pasien HIV/AIDS dalam Menjalani Terapi Antiretroviral di Care Support Treatment RSJ Sungai Bangkong Pontianak. Jurnal Mahasiswa PSPD FK Univ. Tanjungpura. 2018;4(1).

29. Debby C, Sianturi S, Susilo W. Factors Related to Compliance of ARV Medication in HIV Patients at RSCM Jakarta. Jurnal Keperawatan. 2019;10(1).

30. Anggraini R, Wahyono D, Rahmawati F, Gunawan C. Pengaruh Edukasi oleh Apoteker terhadap Kepatuhan Obat Antiretroviral (Arv) pada Pasien Hiv/Aids. In: The 5th Urecol Proceeding. 2017.

31. Galistiani G, Mulyaningsih L. Kepatuhan Pengobatan Antiretroviral pada Pasien HIV/AIDS di RSUD Prof. Dr. Margono Soekarjo Purwokerto. Jurnal Media Farmasi. 2013;10(2):1-10.

32. Horne R, Weinman J, Barber N, Elliot R, Morgan M. Concordance, Adherence and Compliance in Medicine Taking. London: National Co-ordinating Centre for NHS Service Delivery and Organisation; 2005.

33. Husna C. Analisis Dukungan Sosial dengan Kepatuhan Therapy Antiretroviral (ARV) pada Pasien HIV/AIDS di Poliklinik Khusus RSUD. Dr. Zainoel Abidin Banda Aceh. Jurnal Ilmu Keperawatan. 2013;1(1).

34. Sequera, S., Alvares, I. Knowledge and Self-Reported Practice of People Living with Human Immunodeficiency Virus, with Regard to Antiretroviral Therapy (ART) in Mangalore, India. Muller Journal Medical Science and Clinical Research. 2015;6(1):45-8.

35. Khairunnisa, Saraswati L, Adi M, Udiyono A. Gambaran Kepatuhan Pengobatan ARV (Antiretroviral) (Studi pada Wanita Pekerja Seks (WPS) Positif HIV/AIDS di Kabupaten Batang). Jurnal Kesehatan Masyarakat. 2017;5(4):387-95.

36. Hansana V, Sanchaisuriya $P$, Durham J, Sychareun V, Chaleunvong K, Boonyaleepun $S$, et al. Adherence to Antiretroviral Therapy (ART) among People Living with HIV (PLHIV): A CrossSectional Survey to Measure in Lao PDR. BMC Public Health. 2013;13(617).

37. Yuniar Y, Handayani R, Aryastami N. Faktor-Faktor Pendukung Kepatuhan Orang dengan HIV AIDS (ODHA) dalam Minum Obat Antiretroviral di Kota Bandung dan Cimahi. Buletin Penelitian Kesehatan. 2013;41(2).

38. Anwar Y, Nugroho S, Wulandari S. Profile of Antiretroviral Side Effects on Patient of HIV in RSPI Prof. Dr. Sulianti Saroso Jakarta. Jurnal Ilmu Kefarmasian Indonesia. 2018;16(1):49-55. 